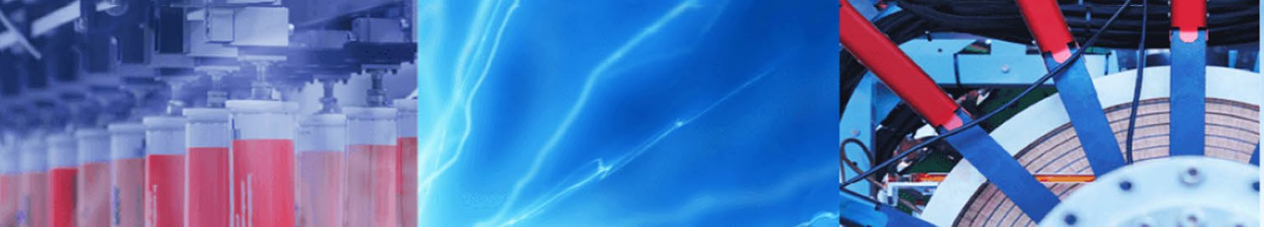

Research Article

\title{
Novel technique for developing flood hazard map by using AHP: a study on part of Mahanadi River in Odisha
}

\author{
Tushar Surwase $^{1}$ (D) P. Manjusree ${ }^{1} \cdot$ P. V. Nagamani ${ }^{2} \cdot$ G. Jaisankar ${ }^{3}$
}

(c) Springer Nature Switzerland AG 2019

\begin{abstract}
In India, Odisha state experienced major natural hazards like floods and cyclones. Floods were experienced fifteen times during 2001-2018 and had two major catastrophic cyclones (super-cyclone 1999 and Phailin 2013). Flood is triggered due to meteorological, hydrological, and terrain conditions at any given place. Considering the terrain parameters namely elevation, slope, drainage density, soil and land use/land cover as the contributing factors for flood inundation, a new technique is developed to calculate flood hazard using analytical hierarchy process (AHP). Using multi-temporal satellite derived flood extent, spatial flood frequency map (SFFM) were generated based on the frequency of inundation. SFFM which represents the observed flood extent on ground at different magnitudes of flood and the terrain conditions on the ground are used synergistically for generating the hazard map. Part of Mahanadi River in Odisha which is highly flood-prone is taken for analysis in this study. More than 100 satellite data sets both microwave SAR and optical data acquired at different magnitudes of flood during 2001-2018 were analysed to prepare the SFFM maps. Pair wise comparison rating was given among flood producing factors and weightage of each factor was computed by using GIS based AHP and multi-criteria evaluation techniques. The individual derived weights (in percentage) of the contributing factors obtained were 50.874 for SFFM, 22.775 for elevation, 10.966 for drainage density, 7.225 for slope, 5.914 for land use and 2.936 for soil. Further, the layers were used in weighted overlay tool and respective weights in percentage were given for generating the flood hazard map in GIS environment. The flood hazard was classified into five hazard classes i.e. very high, high, moderate, low, and very low and corresponding hazard area was estimated to be 7467 ha, 12,871 ha, 28,700 ha, 35,518 ha and 292 ha respectively. These statistics and hazard map will help the concerned local authorities for formulating strategic policies for land use planning and minimize the effect of flood on agricultural land and human lives.
\end{abstract}

Keywords Odisha $\cdot$ Mahanadi River · Spatial flood frequency map · AHP. GIS

\section{Introduction}

From the past two decades, the globe is experiencing a rising trend in occurrence of natural disasters. Hydrological and meteorological disasters are major contributors to it [1]. Asia continent is the world's most disaster prone continent witnessing the highest number of people killed and severely affected by natural disasters and socio economic damage [2]. In India, floods are affecting an average area of 8 million hectares annually and 40 million hectares is the overall area which is susceptible to floods in which $4.18 \%$ (1.672 million hectares) is contributed by

Electronic supplementary material The online version of this article (https://doi.org/10.1007/s42452-019-1233-6) contains supplementary material, which is available to authorized users.

$\triangle$ Tushar Surwase, tusharsurwase@ymail.com; P. Manjusree, pmanjusree@yahoo.com; P.V. Nagamani, pvnagamani@gmail.com; G. Jaisankar, jaisankar_gummapu@rediffmail.com | ${ }^{1}$ Disaster Management Support Group, RSAA, NRSC/ISRO, Hyderabad 500037, India. ${ }^{2}$ Ocean Science Group, ECSA, NRSC/ISRO, Hyderabad 500037, India. ${ }^{3}$ Department of Geo-Engineering, Andhra University, Visakhapatnam, AP 530003, India. 
Odisha state [3]. Floods are a regular feature in Odisha where river network inundates large portion of its catchment area which are low lying along the river network resulting in uprooting houses, disrupting livelihoods and infrastructure damage [4]. In such situations access to the area is cut and there is a lack of communication, collection of information regarding the flood spatial extent, persistence, river flow dynamics, flood water depth and severity in order to carry out relief and rescue operations which are really a challenging task. In order to take quick decision at the time of flood event the availability of flood disaster footprints and its severity is essential $[5,6]$. At the time of severe flood event the conventional ground based flood mapping and aerial observation are time consuming and more expensive and aerial survey sometimes cannot be possible due to hostile weather condition [7]. Satellite observation helps to overcome these difficulties by providing high accuracy flood footprints which helps to assess the disaster impact and decision making in flood mitigation activities. Thus, a series of this high accuracy satellite flood footprints acquired at different magnitude of floods helps to derive a spatial flood frequency map (SFFM) for the study area which represent the major factor for generating flood hazard map. The flood hazard map helps planners and administrators for identification of areas of risk to prioritize the efforts of mitigation, land use policies, resources allocation in case of emergency and it is extremely useful for developing countries where mass population are living in flood prone areas $[8,9]$. Use of multi-temporal satellite images in flood monitoring and management is well documented [10-15]. In the last century, Odisha experienced and witnessed natural disasters for 90 years (floods occurred 49 years, droughts-30 years and cyclones 11 years) [4]. The 1999 super cyclone is having an approximately 50 year return period and almost $90 \%$ of damages in that year is only due to severe flooding and $10 \%$ due to wind damaging roofs, trees and infrastructures [16]. Major floods are observed on the coastal areas as these areas have interaction between marine and terrestrial systems [17]. The protrusion of the coast is occurring due to regular sediments erosion/deposition with MSL rise [18]. Odisha state has a cultivable land of 6.18 million hectares and rice is the principal crop sown [19]. As on 2013, the floods affected 3.61 million people from 5441 villages in the state, 136 blocks in 23 district and 3.2 million hectares rice paddy fields [20]. Paddy fields were swamped during flood at every event resulting reduction in the yield, however, agriculture scientists investigated that flood tolerant rice types (Swarna sub 1) has positive impact on yields, when the flood water persists for 7-14 days in the paddy fields [21]. Floods do not only occurred due to heavy rainfall in the catchment but sometimes they also occur due to release of water from Hirakud dam situated on the upstream side of the study area. Disaster Management Support Division (DMSD), National Remote Sensing Centre/ISRO are monitoring floods since the last two decades. The satellite images comprising of optical and microwave region are procured over the flood-affected regions and the spatial flood extent is monitored using multi-temporal and multi-resolution satellites. Odisha state is experiencing floods twice for every 3 years. Floods were observed 13 times in 18 years in the study area and at some parts in Odisha state they were observed 15 times in 18 years. So, considering the severity and proneness of floods in Odisha, it is very much important to prepare a flood hazard map for designing flood regulation policies. The objective of the proposed study is to develop a flood hazard map for part of Mahanadi River in Odisha by integrating Spatial flood extent (derived from 100 satellite datasets acquired between 2001 and 2018), elevation, drainage density, slope, land use and soil into the GIS based AHP and multi criteria evaluation techniques.

\section{Study area}

Odisha is one of the states in India and surrounded by the Bay of Bengal on the east for $485 \mathrm{~km}$, Chhattisgarh on the west, Jharkhand and West Bengal on the north and Andhra Pradesh on the south. It extends over an area of $155,707 \mathrm{~km}^{2}$ covering about $4.87 \%$ of the total area of India. The maximum and minimum temperature recorded is $41.4^{\circ} \mathrm{C}$ and $12.1^{\circ} \mathrm{C}$ respectively. Odisha state is experiencing four meteorological seasons Southwest monsoon (June to Sept), Northeast monsoon (Oct to Dec), winter (Jan to Feb) and pre-monsoon (March to May). The study area in Odisha lies in between latitudes $20^{\circ} 07^{\prime} 58.8^{\prime \prime} \mathrm{N}$ and $20^{\circ} 43^{\prime} 8.4^{\prime \prime} \mathrm{N}$ and longitudes $84^{\circ} 44^{\prime} 42^{\prime \prime}$ and $85^{\circ} 46^{\prime} 4.8^{\prime \prime}$. Mahanadi is the major river flowing through the study area having a stretch from Tikarapara to Mundali. Tikarapara is one of the gauge-discharge sites on Mahanadi River, set up and maintained by Central Water Commission. The study area covers high mountains, flood plains, deciduous forest and major settlements. The flood plains are most vulnerable to floods and it was affected 13 times over the 18 years studied. Figure 1 shows the location map of the study area.

\section{Data used}

For generating Spatial flood frequency maps, more than 100 historic satellite images between 2001 and 2018 were analysed comprising of Synthetic Aperture Radar (SAR) datasets operating in C band $5.35 \mathrm{GHz}$ in Coarse resolution Scan SAR (CRS) mode $\mathrm{HH}$ polarization (Horizontal Horizontal) acquired 


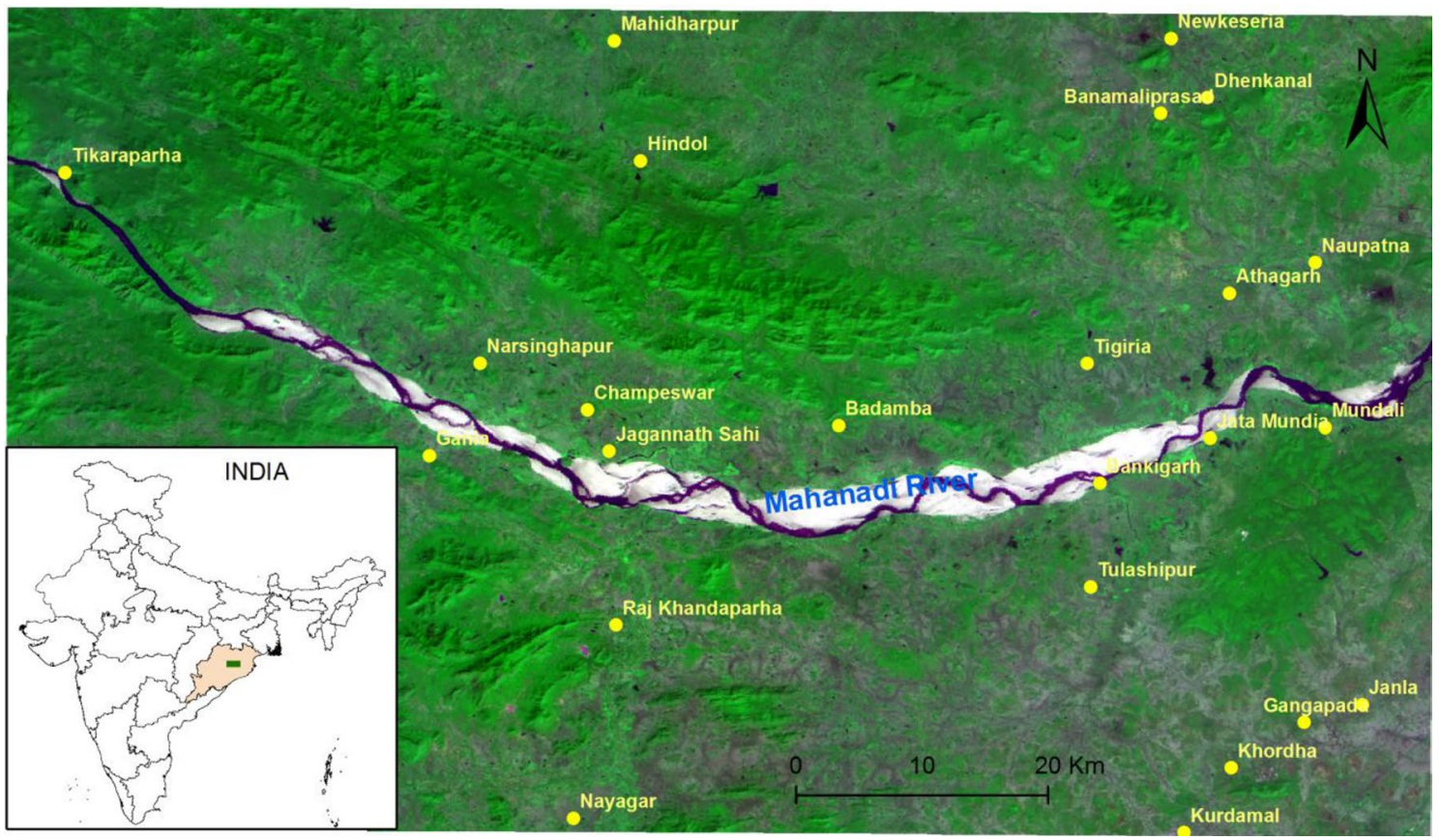

Fig. 1 Location map of study area (IRS, LISS - 3 image) with major settlements

from RISAT-1, Radarsat datasets operated in C band $5.3 \mathrm{GHz}$ Scan SAR wide beam mode in $\mathrm{HH}$ polarization and Sentinel 1-A in $\mathrm{C}$ band $5.3 \mathrm{GHz}$ VH polarization. Optical data from RESOURCESAT-2/2A IRS-AWiFS (Advanced Wide Field Sensor) and MODIS TERRA/ACQUA satellite data was used. Four samples of satellite observed flood images from a series of 100 datasets used for generation of SFFM are shown in Fig. 2. CartoSat, RISAT-1 and IRS-AWiFS are designed, maintained and operated by Indian Space Research Organization (ISRO) Government of India Department of Space and Radarsat is a Canadian satellite maintained by Canadian Space Agency. RISAT-1 and Radarsat have a swath of $220 \mathrm{~km}$ and $500 \mathrm{~km}$ respectively, having spatial resolution of $36 \mathrm{~m}$ and $50 \mathrm{~m}$ respectively. CartoSat $10 \mathrm{~m}$ resolution Digital Elevation Model (DEM) was used to prepare elevation map as shown in Fig. 3; slope map and drainage density are shown in Figs. 4 and 5; Land use Land Cover (LULC) at 1:250.000 scale was used for land use map which is derived from AWiFS as shown in Fig. 6 and soil data was used for soil map as shown in Fig. 7. All these datasets used are developed by National Remote Sensing Centre/Indian Space Research Organization (ISRO).

\section{Methodology}

\subsection{Development of SFFM}

Development of SFFM involves flood layer extraction/ delineation from satellite data, integration of all flood layers generated within a year to form an annual flood layer, integration of all annual layers in order to generate spatial flood frequency. The adopted methodology for generating SFFM is shown in Fig. 8.

\subsubsection{Pre-processing of SAR images}

For continuous monitoring of floods, SAR data is superior to optical sensors data due to its ability to penetrate through clouds which are generally covered during floods [22]. For floods, $\mathrm{HH}$ polarization with incidence angle $20^{\circ}-49^{\circ}$ is preferred than $\mathrm{V} V$ polarization for better discrimination of smooth surface (water) [23-25]. For the present study, $\mathrm{HH}$ polarization is used for all the SAR datasets. In order to generate flood layer, the raw SAR image were preprocessed for radiometric calibration and a $3 \times 3$ Gamma Maximum A Posteriori (MAP) filter was applied. This filter is preferred as it removes high-frequency noise (speckle) while preserving high-frequency features (edges). It is a high capability of speckle smoothing than Lee-sigma and frost [26]. Further, the filtered images were converted to sigma nought image in $\mathrm{db}$ (decibel) using the Eq. 1 given below.

SIGMAij $=10.0 \times \log 10((D N \times D N+A 0) A j)+10.0 \times \log 10(\sin (\mathrm{lj}))$

where SIGMAij is the output backscatter coefficient in decibels for scan line $i$, pixel $j, \log 10$ is the logarithm to the base 10; DN is the input image value for scan line $i$, pixel 


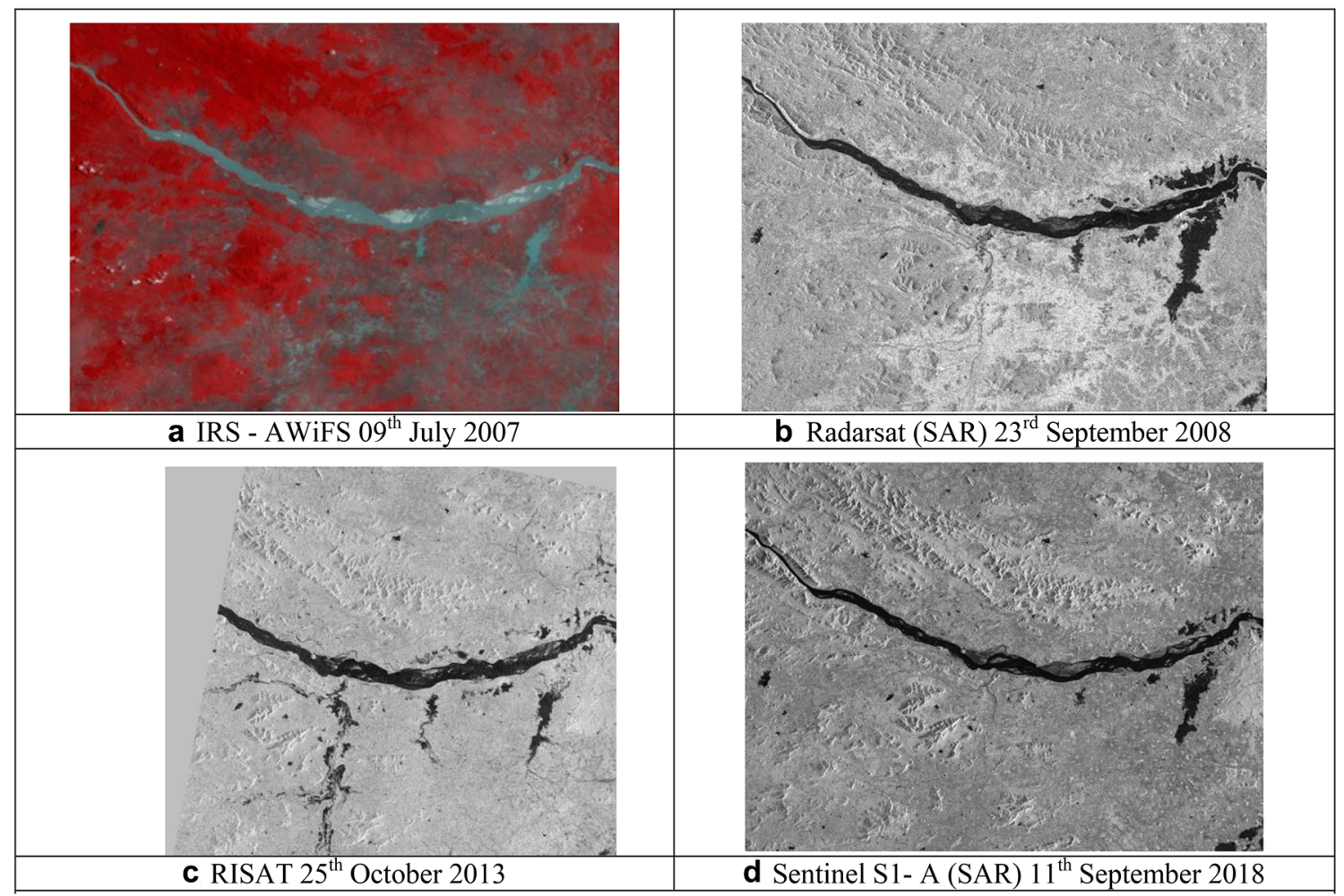

Fig. 2 Four sample satellite observed flood images from a series of 100 datasets used for generation of SFFM. a IRS-AWiFS observed on 09th July 2007, b Radarsat (SAR) observed on 23rd September
2008, c RISAT observed on 25th October 2013, d Sentinel S1-A (SAR) observed on 11th September 2018

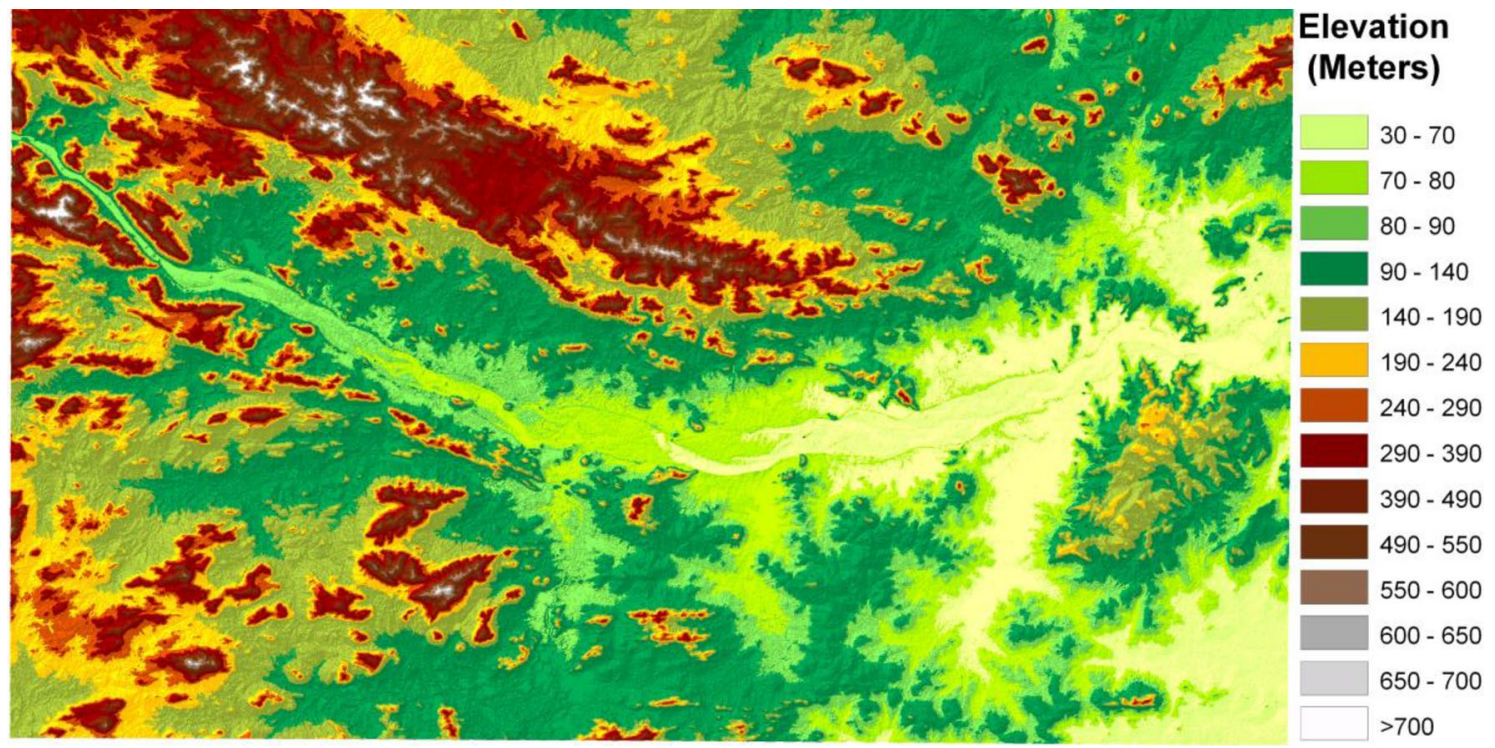

Fig. 3 Digital elevation model (DEM) derived from CARTOSAT satellite

$\mathrm{j} ; \mathrm{AO}$ is the gain offset from the first member of AOSEG; $\mathrm{Aj}$ is the expanded gain scaling table value for column $\mathrm{j}$; sin is the sine trigonometric function; and $\mathrm{l} j$ is the incident angle (expanded) table value for column $\mathrm{j}$. Later, the sigma nought images were geometrically corrected with the master images in the projected co-ordinate system (PCS) Lambert conformal conic projection.

\section{SN Applied Sciences}




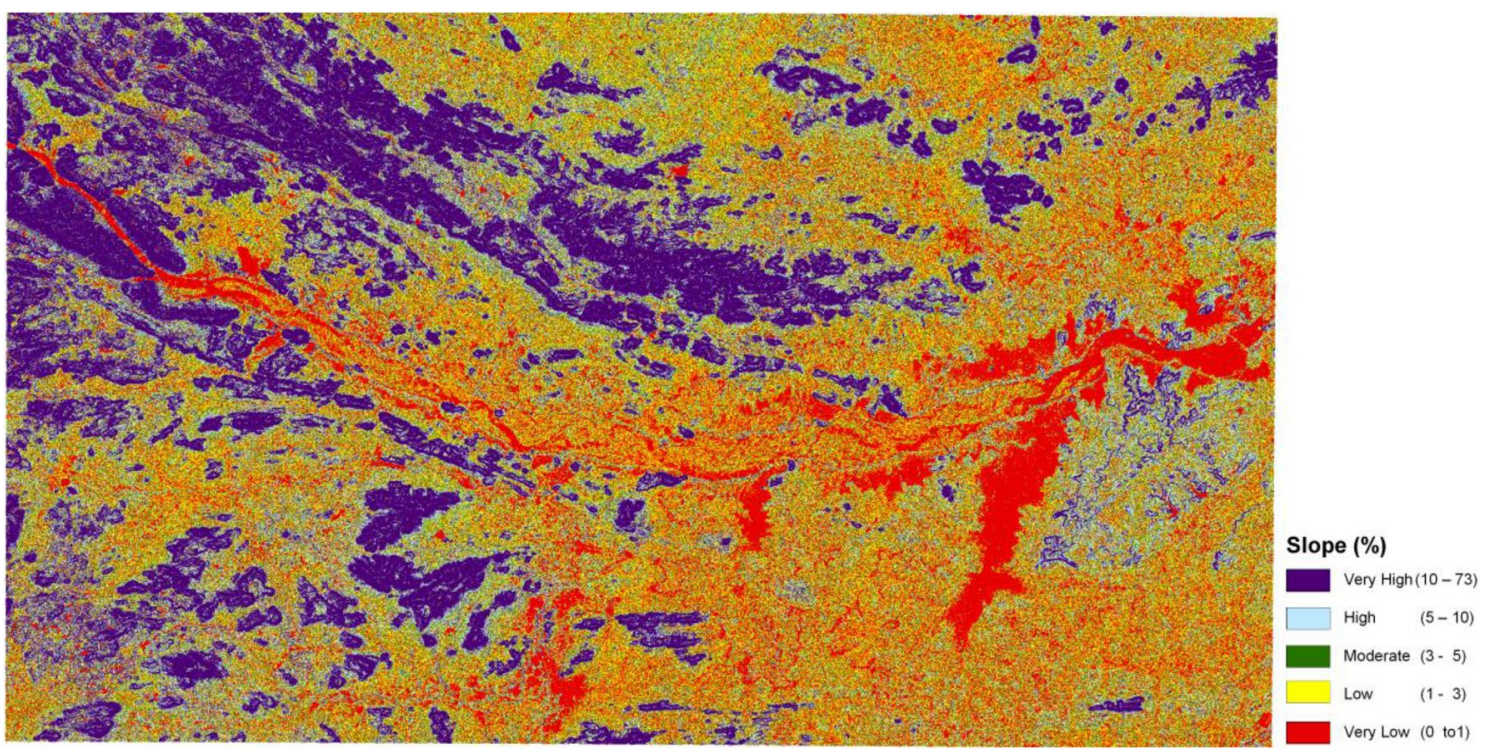

Fig. 4 Slope for study area generated from above DEM

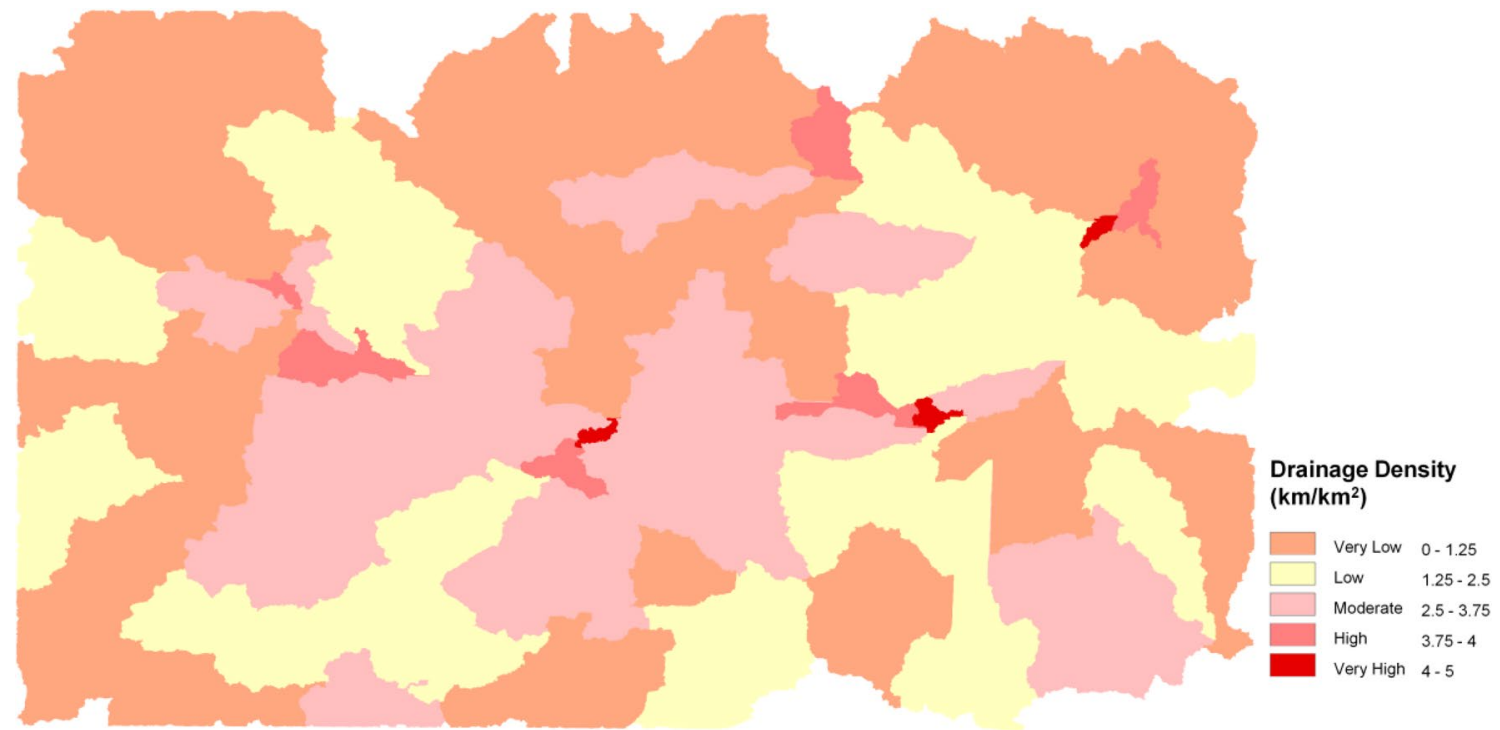

Fig. 5 Drainage density for study area generated from above DEM

\subsubsection{Extraction of water layer/inundation layer from SAR images}

In SAR imagery water areas are represented in dark tone due to very low backscatter [27]. The backscatter intensity range in between -25 and $-18 \mathrm{db}$ is congenial for classification of water. Thus intensity range in between -25 and $-18 \mathrm{db}$ is considered as water layer pixels and others as non-water pixels. For the present study variable incidence angle threshold technique was used for classification of flood water layer. A pre-flood water-body mask layer is prepared by analysing pre-flood satellite image and river bank, river, lakes, ponds are delineated. The flood water layer is intersected with the mask layer and final flood inundation layer is extracted.

\subsubsection{Extraction of water layer from optical images}

K-means algorithm was used to classify the water from optical images. Here, the convergence threshold value is set to be 0.95 , number of clusters as 20 and number of iterations as 40 . In each iteration, pixels are reclassified 


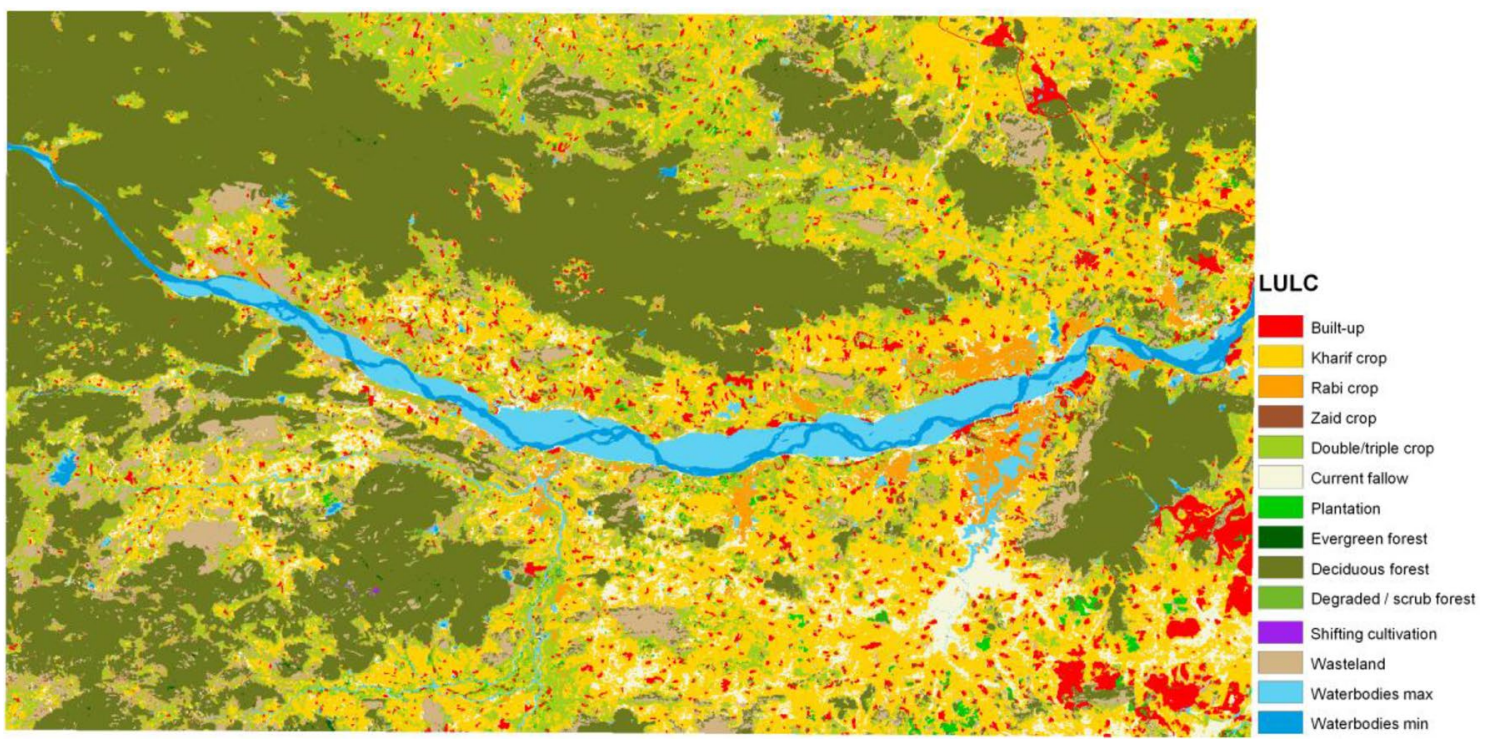

Fig. 6 Land use land cover derived from AWiFS

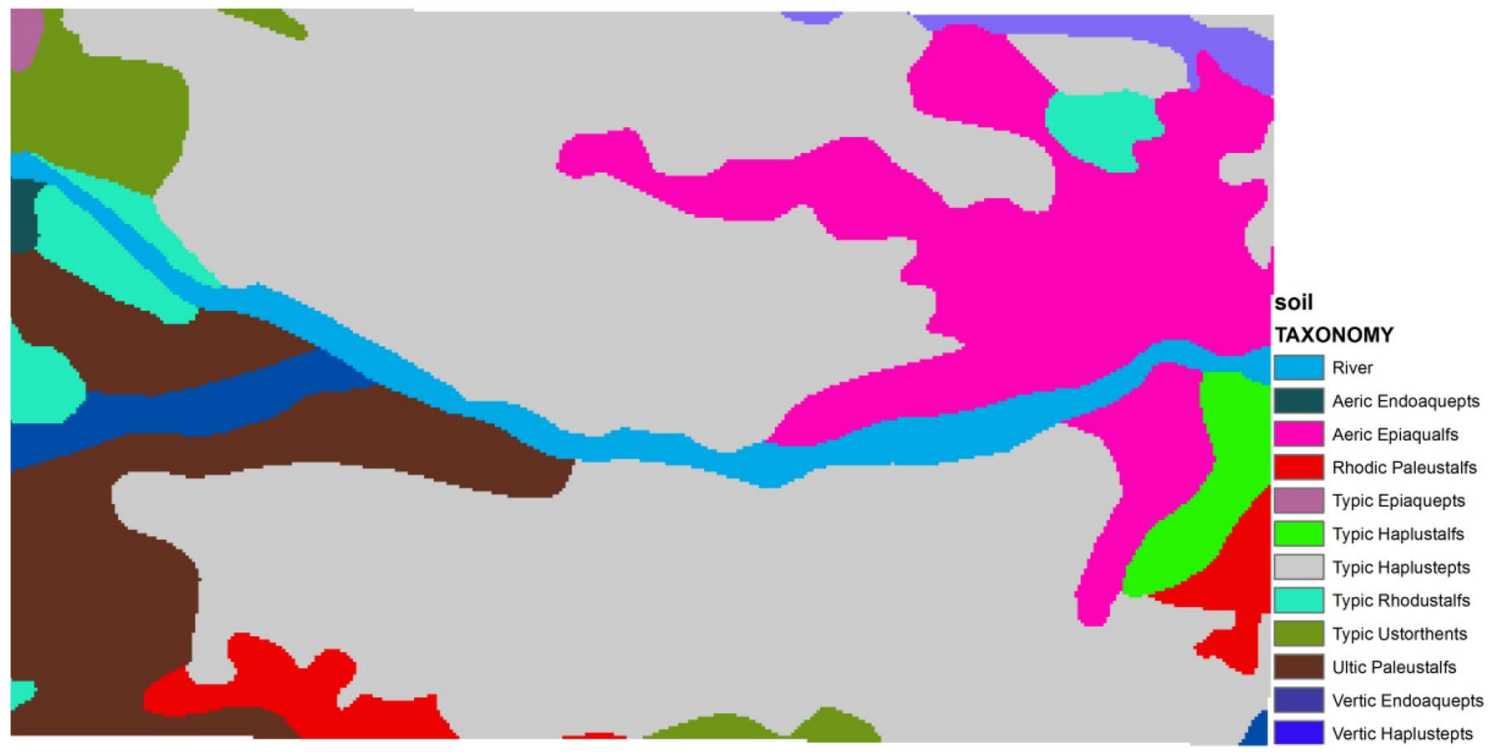

Fig. 7 Types of soil

to the nearest class by reiterating the mean till maximum number of iteration ( 20 for study analysis) is reached. It is masked with the pre-flood water-body layer to form flood inundation layer. The SFFM obtained is depicted in Fig. 9a.

\subsubsection{Integration of flood layers}

All the individual flood layers in the same year were integrated into one flood layer called annual flood layer and all annual flood layers from 2001 and 2018 are further integrated to compose SFFM. The integration of flood layers was done in ERDAS software by addition (+) of flood layers to make an annual flood layer. The following Eq. 2 shows the integration of all annual flood layers for generating SFFM layer.

$$
\begin{aligned}
\text { SFFM }= & (1 \text { st Annual layer }) \times 1+(2 \text { nd Annual layer }) \\
& \times 1+(3 \text { rd Annual layer }) \\
& \times 1+(\text { nth Annual layer }) \times 1
\end{aligned}
$$

\section{SN Applied Sciences}


Fig. 8 Methodology flow chart for generating SFFM

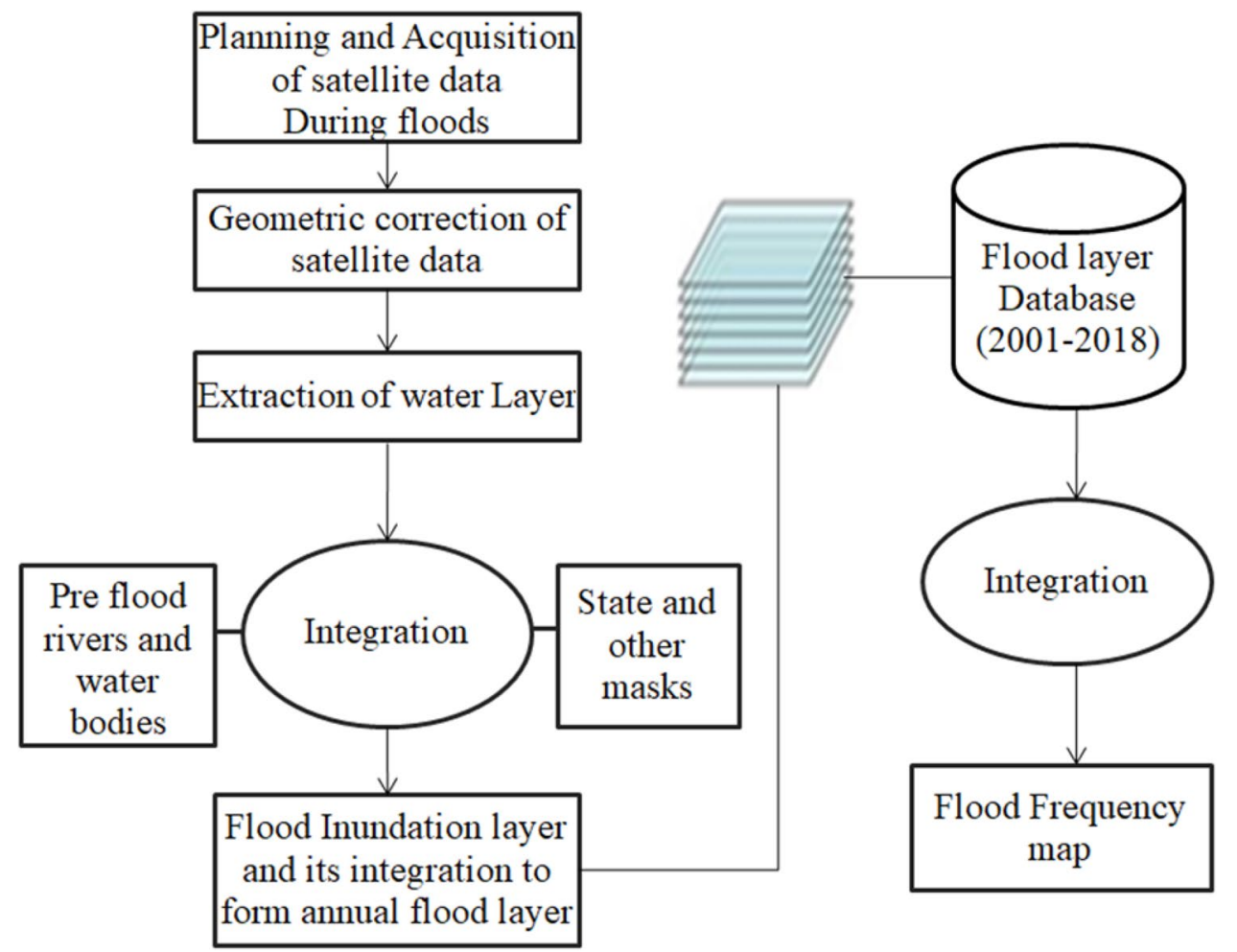

\subsection{Classification of the model parameters}

Each model parameter was classified into five classes; very high, high, moderate, low and very low. SFFM is classified based on the frequency of flood arrival; the frequency falling in between $9-13$ times in 18 years is considered as very high class; 6-9 times as high; 3-6 times as moderate; $2-3$ times as low and 1-2 times as very low. The lowest elevation is first affected by flood and is classified as very high $(30-70 \mathrm{~m})$, high $(70-80 \mathrm{~m})$, moderate $(80-90 \mathrm{~m})$, low (90-140 m) and very low (140-190 m). Drainage density is the ratio of total drainage length in the catchment to the total area of the catchment. Catchments with high drainage density produce maximum flood. Hence, schema was made as on the density $4-5 \mathrm{~km} / \mathrm{km}^{2}$ as very high; $3.75-4 \mathrm{~km} / \mathrm{km}^{2}$ as high, $2.5-3.75 \mathrm{~km} / \mathrm{km}^{2}$ as moderate; $1.25-2.5 \mathrm{~km} / \mathrm{km}^{2}$ as low and $0-1.25 \mathrm{~km} / \mathrm{km}^{2}$ as very low. In case of slope, the higher the slope, the more is the accumulation of water. Hence, $10-73 \%$ is considered as very high, $5-10 \%$ as high, $3-5 \%$ as moderate, $1-3 \%$ as low and $0-1 \%$ as very low. Since LULC has 14 range of classes within the study area, it has been regrouped into 5 classes namely agriculture, built up, plantation, forest and wastelands. Kharif, rabi, zaid, double/triple and current fallow are clustered into agriculture and was assigned very high class, built-up as high, plantation as moderate, wasteland as low and evergreen, deciduous and degraded forests are clustered into forest and are assigned as very low class. Since soil has 11 classes in the study area, it has been regrouped into 5 classes according to their physical properties. In the study area, large portion is covered by 'Typic Haplustepts' class which is dominated by clay. Clayey soils have a high porosity but less infiltration capacity and thus lead to high runoff. Other soil type contains clay, sandy loam and silt. Soil Typic Haplustepts is assigned as very high class; Aeric Epiaqualfs as high class; Typic Rhodustalfs, Ultic Paleustals and Vertic Endoaquepts are regrouped and assigned as moderate class; Rhodic Paleustalfs, Typic Haplustalfs and Vertic Haplustepts are regrouped and assigned as low class and Aeric Endoaquepts, Typic Epiaquepts, Typic Ustorthents are regrouped and assigned as very low class. The above classification schema is assigned as per the literature survey and available ground information. All the layers classified with the above schema are shown with the legend in Fig. 9a-f.

\subsection{Assessment of flood hazard using AHP}

A pairwise comparison was made between six flood producing factors i.e. SFFM, elevation, drainage density, slope, LULC and soil using AHP. The pairwise matrix was formed based on Satty's scale weights for pair comparison as shown in Table 1. The pair comparison is the key component of the AHP wherein, each flood producing parameter was compared with another. In the first step, the pairwise 


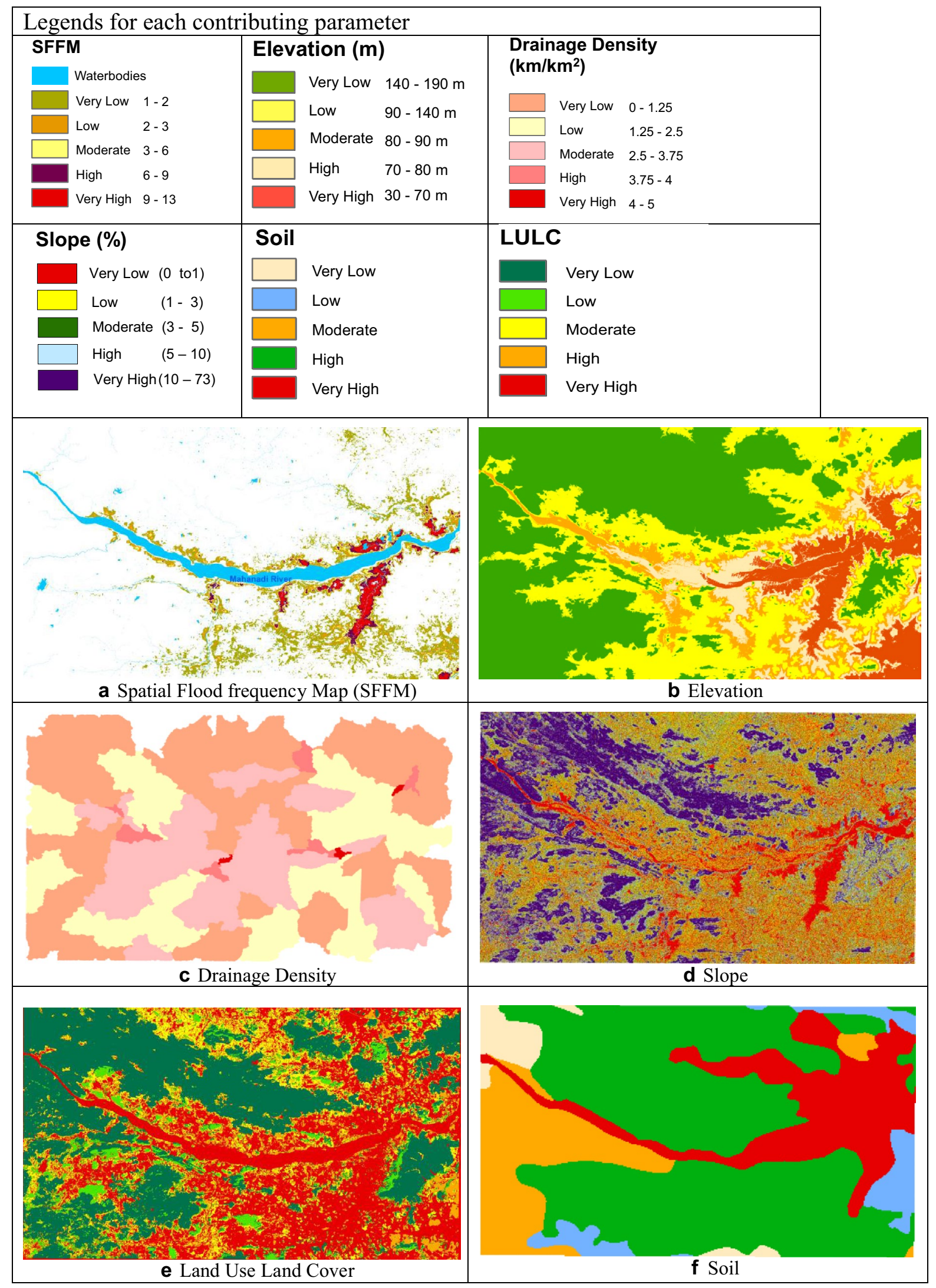

Fig. 9 a Spatial flood frequency map; b elevation; $\mathbf{c}$ drainage density; $\mathbf{d}$ slope; $\mathbf{e}$ land use land cover; $\mathbf{f}$ soil 
matrix is determined using the Eigen vector $(V p)$ as shown by Eq. 3

$V p=\sqrt[k]{W 1 \times W 2 \times \ldots W k}$

where $\mathrm{k}$ is the number of parameters in comparison, and $\mathrm{W} 1$ and $\mathrm{Wk}$ are the weights of criterion 1 and $\mathrm{k}$, respectively.

In the second step the weighting coefficient $\left(C_{p}\right)$ is calculated by using Eq. 4

$C p=\frac{V p}{V p 1+V p 2+\ldots V p k}$

The third step computes the Eigen value ( $\lambda$ max) using Eq. 5

$\lambda_{\max }=\frac{[E]}{k}$

where $[E]$ is the rational priority which can be determined by Eq. 6

$[E]=\frac{\sum \text { Row of normalization matrix }}{C p}$

The matrix was normalized by dividing each component of the column by summation of the column.

In the fourth step consistency index $(\mathrm{Cl})$ is calculated using Eq. 7

$\mathrm{Cl}=\frac{(\lambda \max -k)}{(k-1)}$

Finally the consistency ratio $(\mathrm{CR})$ is determined using Eq. 8

$\mathrm{CR}=\frac{C l}{R l}$

where $\mathrm{Rl}$ is the Random Index values as given by Satty in 1980 [28] for different number of criteria as shown in Table 2.

Several pair combinations were made to choose the optimum consistency ratio and the pair combination whose consistency ratio is under $10 \%$ or 0.1 by value is selected $[29,30]$. The pair wise matrix as shown in Table 3 is used to calculate individual Eigen weights using AHP tool in Arc GIS. Table 4 shows the obtained Eigen weights for the study area.

The most used approach for overlay analysis is 'weighted overlay' tool for solving multi-criteria problems such as site selection and suitability models. Hence, the individual weights value was given to each respective raster in 'weighted overlay tool' in ArcGIS software. Weighted overlay tool overlays several raster layers using a common measurement scale and weights each according to its importance. Figure 10 illustrates two input raster layers that have been reclassified to a common measurement scale of 1-3. Each raster is assigned a percentage influence. The raster cell values are multiplied by their weightage or influence, and the results are added together to create new output raster. For example, consider the upper left cell. The values for the two inputs become $(2 \times 0.75)=1.5$ and $(3 \times 0.25)=0.75$. The sum of 1.5 and 0.75 is 2.25 . As the new output raster from weighted overlay is integer, the final raster cell value is rounded to 2 . Similarly, six raster layers (flood producing factors) were accounted and hazard map was generated by using the Eq. 9 . Figure 11 shows the end to end methodology for computing the flood hazard map.

$$
\begin{aligned}
\text { Flood hazard }= & \{0.50874 \times[\text { SFFM }]+0.2275 \times[\text { Elevation }] \\
& +0.1996 \times[\text { Drainage density }]+0.7255 \\
& \times[\text { slope }]+0.05914 \times[\text { LULC }] \\
& +0.02936[\text { Soil }]\}
\end{aligned}
$$

Table 2 Random index for different number of criteria [28]

\begin{tabular}{ll}
\hline Number of criteria & $\begin{array}{l}\text { Random } \\
\text { index (RI) }\end{array}$ \\
\hline 2 & 0.00 \\
3 & 0.58 \\
4 & 0.90 \\
5 & 1.12 \\
6 & 1.24 \\
7 & 1.32 \\
8 & 1.41 \\
9 & 1.45 \\
10 & 1.49 \\
11 & 1.51 \\
\hline
\end{tabular}

Table 1 Modified Satty's scale weights for pair comparison

\begin{tabular}{lll}
\hline Scale & Numerical rating & Explanation \\
\hline Equally important & 1 & Two activities contributing equally \\
Extremely important & $1 / 9$ & The evidence favouring one activity over another is of the highest possible \\
Very strongly & $1 / 7$ & An activity is favoured very strongly over another \\
Strongly & $1 / 5$ & Judgement and experience strongly one activity over another \\
Moderately & $1 / 3$ & Experience and judgement slightly to moderately favour one activity to another
\end{tabular}


Table 3 Pair wise comparison matrix between flood contributing factors

\begin{tabular}{lllllll}
\hline & SFFM & Elevation & $\begin{array}{l}\text { Drainage } \\
\text { Density }\end{array}$ & Slope & LULC & Soil \\
\hline SFFM & $\mathbf{1}$ & & & & & \\
Elevation & $1 / 3$ & $\mathbf{1}$ & & & \\
Drainage density & $1 / 9$ & $1 / 5$ & $\mathbf{1}$ & & \\
Slope & $1 / 9$ & $1 / 3$ & $1 / 3$ & $\mathbf{1}$ & $\mathbf{1}$ & \\
LULC & $1 / 7$ & $1 / 3$ & $1 / 3$ & $1 / 3$ & $1 / 3$ & $\mathbf{1}$ \\
Soil & $1 / 7$ & $1 / 7$ & $1 / 5$ & $1 / 3$ & & \\
\hline
\end{tabular}

Table 4 Eigen individual weights for flood inundation factors

\begin{tabular}{lc}
\hline Contributing factors & Individual weights \\
\hline SFFM & 50.874 \\
Elevation & 22.775 \\
Drainage density & 10.996 \\
Slope & 7.255 \\
LULC & 5.914 \\
Soil & 2.936 \\
\hline
\end{tabular}

where multiplying coefficients $(0.50874,0.2275,0.1996$, $0.7255,0.05914$, and 0.02936 ) are called as individual Eigen value or percentage influence.

From the above Eq. 9, output raster cell values are of the order 1, 2, 3, 4 and 5. The threshold used for generating flood hazard map for very low, low, moderate, high and very high severities was 1, 23, 4 and 5 respectively.

\section{Results and discussion}

The flood hazard map was developed by accounting flood producing factors i.e. SFFM, elevation, drainage density, slope, LULC and soil using GIS based AHP techniques and weighted overlay. The extent of flood hazard map is taken as per the flood footprints of SFFM. The area corresponding to each flood hazard class and percentage of flood hazard area with respect to total hazard area are shown in Table 5.

Fig. 10 Illustration of weighted overlay tool

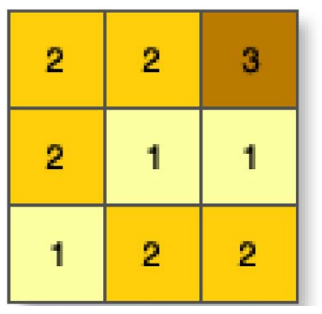

In Raster 1 (Influence 75\%)
The hazard area 7467, 12,871, 28,700, 35,518, 292 ha and percentage hazard area with respect to total hazard area $8.81,15.17,33.82,41.86,0.34 \%$ correspond to very high, high, moderate, low, very low hazard classes respectively. The flood hazard map depicts that very high and high flood hazard are falling in the low lying areas of the study where SFFM is nearly about 09-13 times in 15 years. The Fig. 12 shows computed flood hazard map for the study area. The low flood hazard covers the largest area which is $41.86 \%$ of total area followed by moderate $(33.82 \%)$, high $(15.17 \%)$, very high $(8.81 \%)$, very low (0.34\%). The map shows that towns like Tulashipur, Jatamundia, Mundali, Bankigarh, Athagarh, Naupatna, Jalna, Gania, Raj Khandarparha and Nayagar are severely affected towns. The rainfall parameter is not used for computing the hazard map because, after rainfall, runoff is generated in the form of discharge and meet the discharge into the water bodies (river) at place far from the point of observed rainfall and later results in inundation along the river, thus, including observed rainfall map may affect the accuracy of map. For e.g. the rainfall falling on mountains due to orographic precipitation is more than in low lying areas. So, in such case, if we take rainfall map parameter in account for hazard generation, mountainous/hilly region will be assigned very high class of hazard but in reality there will be no flooding on mountains or hilly regions. Flooding will be there in low lying or on the flat terrain along the river and thus it may affect the accuracy of hazard map.

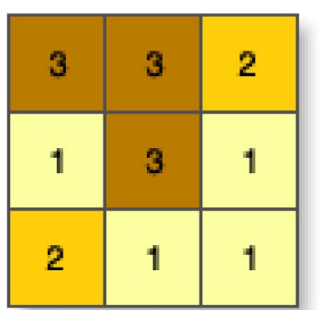

In Raster 2 (Influence 25\%)

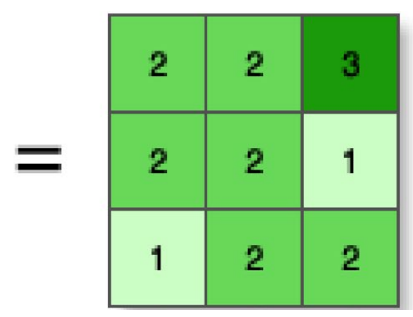

Output Rasters 


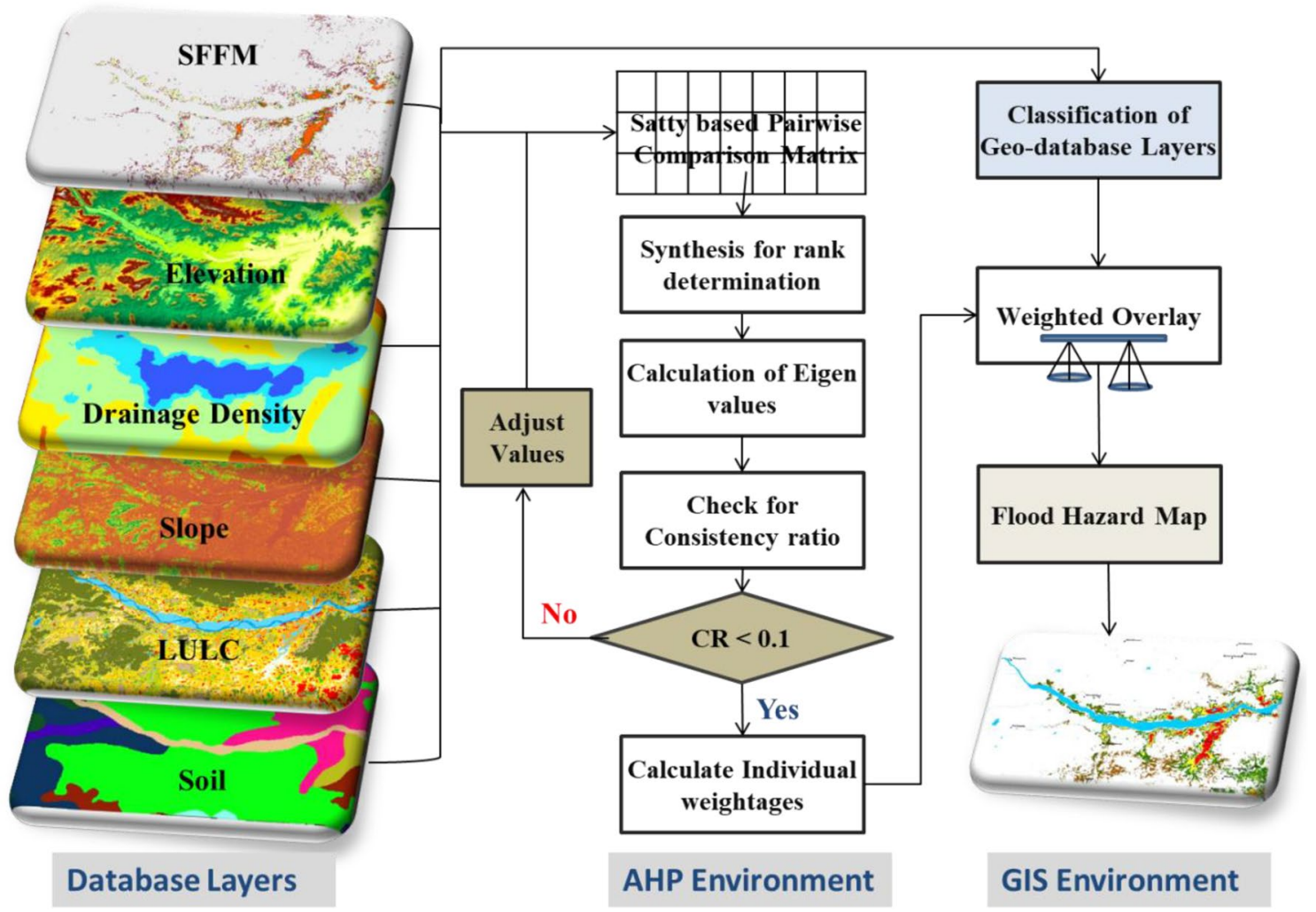

Fig. 11 Methodology for computing the flood hazard map

Table 5 Flood hazard map statistics

\begin{tabular}{llcl}
\hline S. no & Flood hazard classes & Hazard area (ha) & $\begin{array}{l}\text { \% flood } \\
\text { hazard } \\
\text { area }\end{array}$ \\
\hline 1 & Very high & 7467 & 8.81 \\
2 & High & 12,871 & 15.17 \\
3 & Moderate & 28,700 & 33.82 \\
4 & Low & 35,518 & 41.86 \\
5 & Very low & 292 & 0.34 \\
Total & & 84,848 & 100 \\
\hline
\end{tabular}

\subsection{Comparison}

The hazard map using AHP was compared with SFFM technique. In SFFM technique hazard map is only based on classification of SFFM observed by satellite images (refer Fig. 9a) [31]. Whereas in AHP technique, it includes all other flood producing factors including SFFM. In SFFM technique it is observed that the number of villages falling in the very high, high, moderate, low and very low class for an study area are 147, 253, 439, 742 and 1321, whereas, for AHP technique the number of villages falling are 147, $376,814,1297$ and 126 respectively. The comparison chart for AHP and SFFM technique is shown in the Fig. 13. It is observed that there is a significant increase in the number of villages falling in the very low class and low hazard category. Number of villages falling in very high hazard class is the same for both the techniques. It can be inferred that the number of villages (in SFFM technique) which are in very low class have migrated to low, moderate and high class in AHP technique. This is a very important result obtained by this technique since more priority needs to be given on these migrated villages for implementing policies for land use planning, minimizing the effect of flood on agricultural land and human lives and constructing control structures for disaster risk reduction. Further, the villages in low hazard (in SFFM technique) have migrated to moderate hazard in AHP technique where priority needs to be given. The study also revealed that coupling both satellite data observations and ground terrain conditions produce better flood hazard intensity of the region in a realistic way.

\subsection{The severe flood event in September 2008}

In the year 2008, Mahanadi River was hit by severe flood in September due to heavy rainfall in the catchment and subsequent increase in the discharge. The 


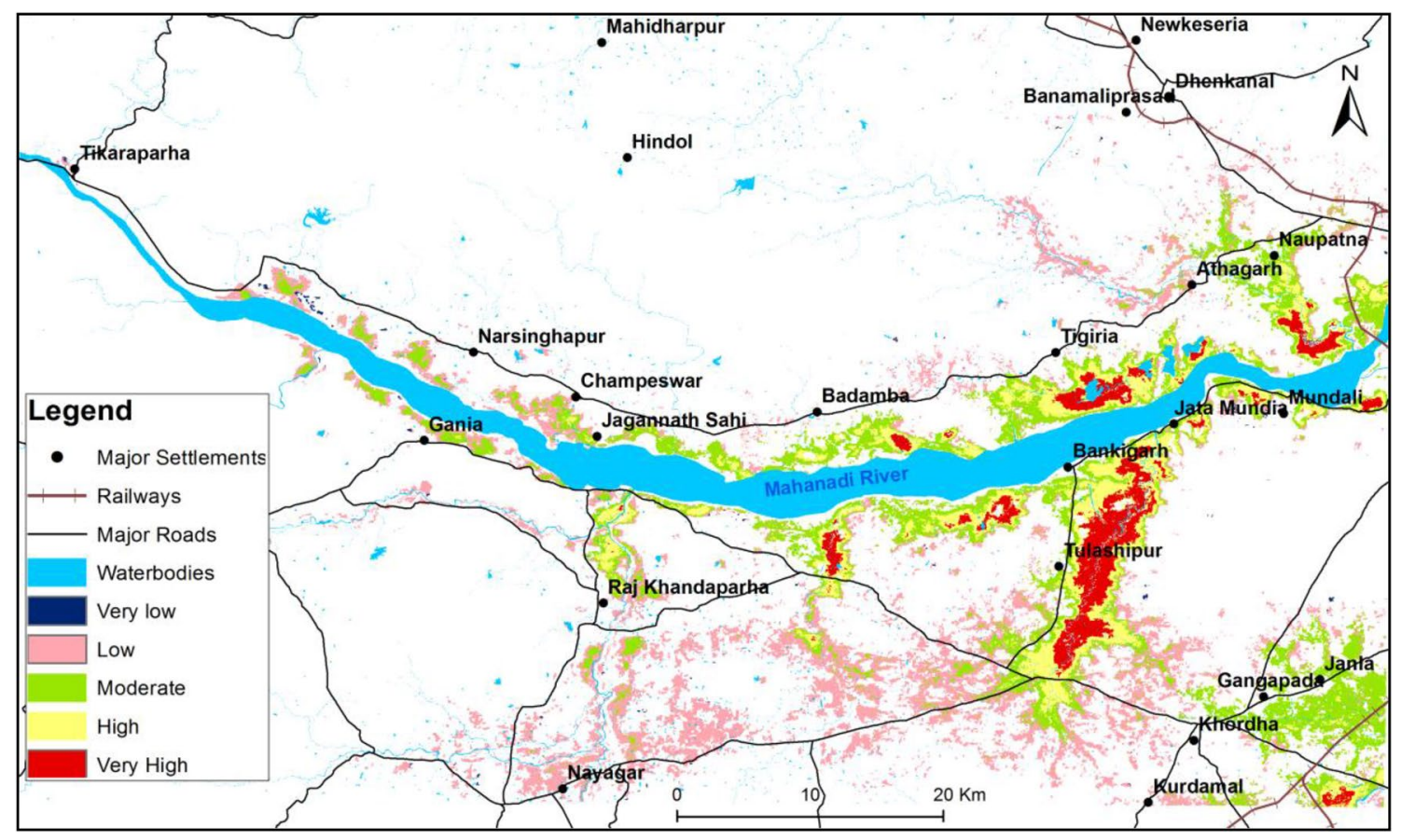

Fig. 12 Flood hazard map for the study area

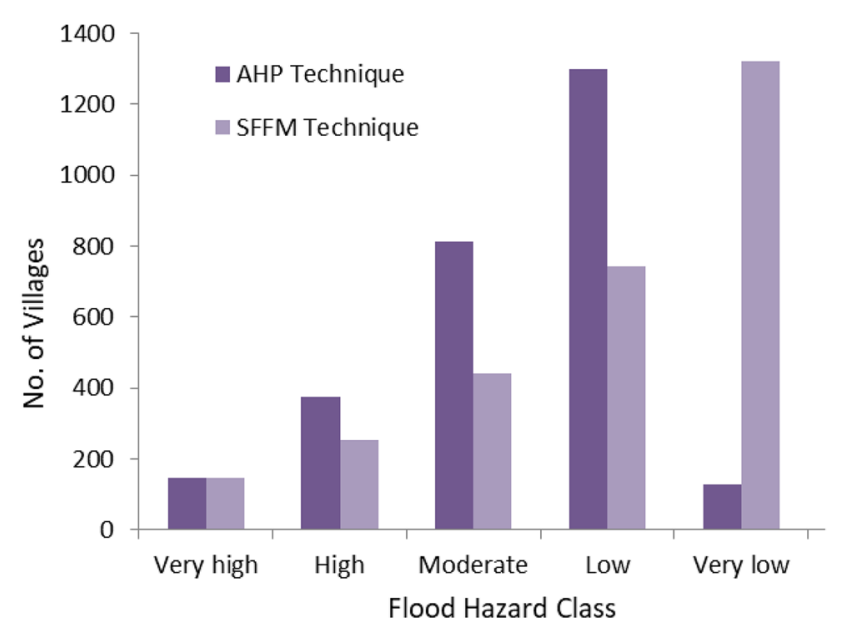

Fig. 13 Number of villages in different hazard class as per SFFM and AHP technique

flow hydrograph collected at Tikarapara station from Central Water Commission (CWC) indicates sudden rise recorded by the hydrograph on 18th September 2008 as shown in Fig. 14. This gave rise to floods and affected major districts like Cuttack and Khurda. Satellite images were acquired at the peak flood and also during the recession. The extent and pattern of flooding can be seen in the satellite images as shown in Fig. 15. On 20th September maximum inundation was observed which remained for several days and subsequently the flood was receded on 30th September 2008 as observed in the hydrograph also.

\section{Conclusion}

The present study explained a novel technique using AHP to calculate flood hazard by combining the satellite derived flood extent and the contributing factors for inundation like elevation, drainage, elevation, slope, land use/land cover and soil. The hazard area of $7467 \mathrm{ha}$, $12,871 \mathrm{ha}, 28,700 \mathrm{ha}, 35,518 \mathrm{ha}, 292 \mathrm{ha}$ and percentage hazard area with respect to total hazard area $8.81 \%$, $15.17 \%, 33.82 \%, 41.86 \%, 0.34 \%$ corresponding to very high, high, moderate, low and very low hazard classes respectively. The low flood hazard class covers the largest area which is $41.86 \%$ of the total flood hazard area followed by moderate (33.82\%), high (15.17\%), very high $(8.81 \%)$, very low $(0.34 \%)$. The map shows towns like Tulashipur, Jatamundia, Mundali, Bankigarh, Athagarh, Naupatna, Janla, Gania, Raj Khandarparha and Nayagar are severely affected towns and hence disaster preparedness plans for these towns are to be given high priority. 


\section{Flow Hydrograph at Tikarpara Station on September 2008}

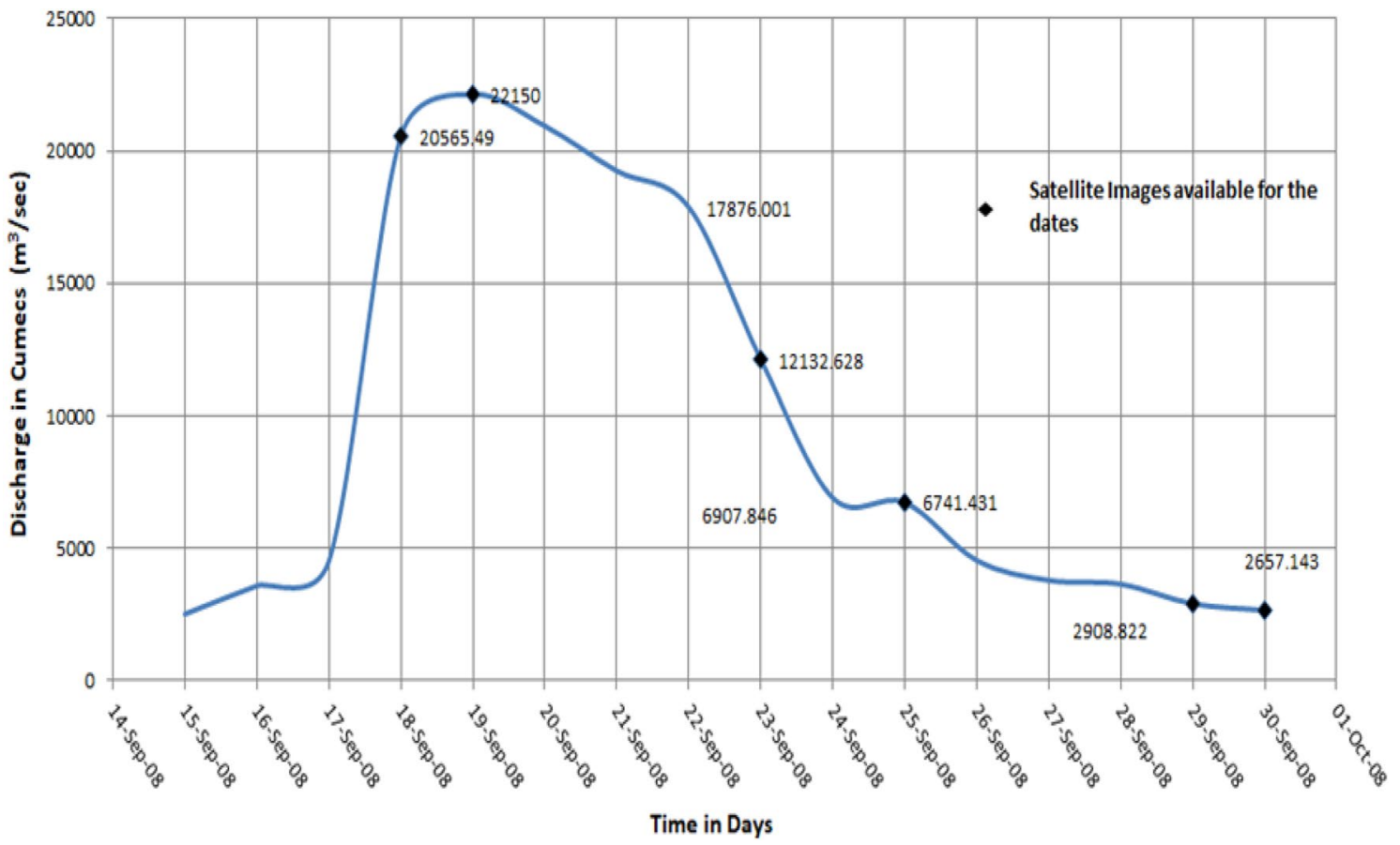

Fig. 14 Flow hydrograph at Tikarpara station on Mahanadi River in September 2008 satellite images available is shown in filled diamond shape

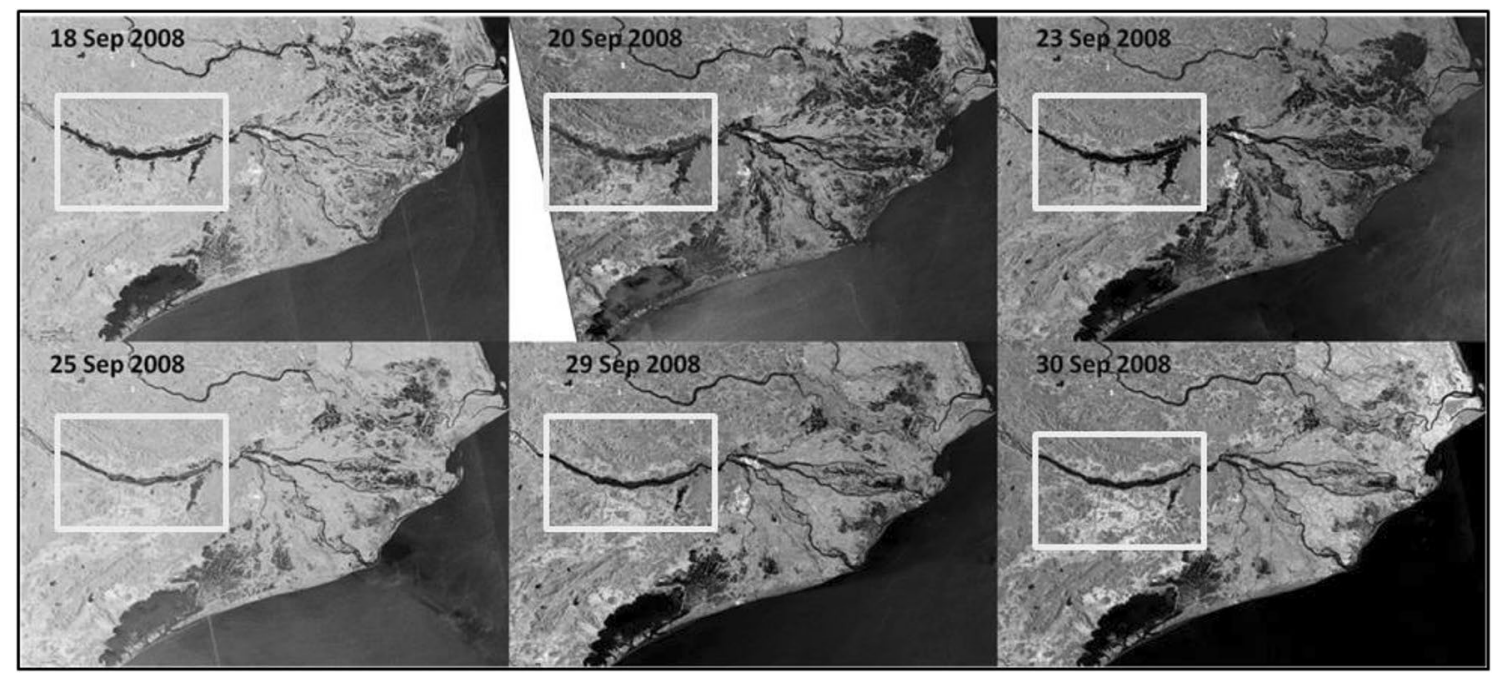

Fig. 15 Satellite images showing inundation variation with respect to time (black signature indicates flood inundation) and the study area is shown in the box

The flood hazard map can help to manage the disaster event and take necessary action for mitigation measures and also it can be used for formulating strategic policies of land use which intends to minimize the effect of flood on agricultural land and human lives. 
Acknowledgements The authors would like to thank European Space Agency for providing the Sentinel-1 data and NASA for providing MODIS data free of cost. The author would like to extent sincere thanks to Director NRSC, DD RSA, NRSC, Dr. KHV Durgarao Head DMSD, Mr SVSP Sharma, DMSD and other colleagues in DMS division without which the study would not have been completed.

\section{Compliances with ethical standards}

Conflict of interest The authors declare that they have no conflict of interest.

\section{References}

1. Skakun S, Kussul N, Shelestov A, Kussul O (2014) Flood hazard and flood risk assessment using a time series of satellite images: a case study in Namibia. Risk Anal 34(8):1521-1537. https://doi. org/10.1111/risa.12156

2. Iwasaki Shimpei (2016) Linking disaster management to livelihood security against tro-pical cyclones: a case study on Odisha state in India. Int J Disaster Risk Reduct 19:57-63. https://doi. org/10.1016/j.ijdrr.2016.08.019

3. Sharma VK, Kaushik Ashutosh D (2012) Natural disaster management in India. YOJANA Publishing. https://www.insightsonindia .com/wp-content/uploads/2013/09/natural-disaster-manag ement-in-india.pdf. Accessed March 2012

4. Roy BC, Mruthyunjaya, Selvarajan S (2002) Vulnerability to climate induced natural disasters with special emphasis on coping strategies of the rural poor in coastal Orissa, India Vigyan Bhavan, New Delhi, India. https://unfccc.int/cop8/se/se_pres/isdr_pap_cop8. pdf. Accessed 23-1 Nov 2002

5. Miranda FP, Fonseca LEN, Carr JR (1998) Semivariogram textural classification of JERS-1 (Fuyo-1) SAR data obtained over a flooded area of the Amazon rainforest. Int J Remote Sens 19(3):549-556. https://doi.org/10.1080/014311698216170

6. Okamoto K, Yamakawa S, Kawashima H (1998) Estimation of flood damage to rice production in North Korea in 1995. Int J Remote Sens 19(2):365-371. https://doi.org/10.1080/014311698216332

7. Brivio PA, Colombo R, Maggi M, Tomasoni R (2002) Integration of remote sensing data and GIS for accurate mapping of flooded areas. Int J Remote Sens 23(3):429-441. https://doi. org/10.1080/01431160010014729

8. Manjusree P, Bhatt CM, Begum A, Rao GS, Bhanumurthy V (2015) A decadal historical satellite data nalysis for flood hazard evaluation: a case study of Bihar (North India). Singap J Trop Geogr 36:308-323

9. Sanyal J, Lu X (2006) GIS-based flood hazard mapping at different administrative scales: a case study in Gangetic West Bengal, India. Singap J Trop Geogr 27:207-220. https://doi.org/10.111 1/j.1467-9493.2006.00254.x

10. Rango A, Salomonson V (1973) Repetitive ERTS-1 observations of surface water variability along rivers and low-lying areas. https:// ntrs.nasa.gov/search.jsp?R=19740044139. Accessed 01 Jan 1973

11. Hallberg GR, Hoyer BE, Rango A (1973) Application of ERTS1 imagery to flood inundation mapping. NASA Special Publication No. 327, https://ntrs.nasa.gov/archive/nasa/casi.ntrs.nasa. gov/19730008741.pdf. Accessed 09 March 1973

12. Islam MdM, Sado K (2000) Development of flood hazard maps of Bangladesh using NOAA-AVHRR images with GIS. Hydrol Sci J 45(3):337-355. https://doi.org/10.2208/prohe.44.301

13. Islam MM, Sado K (2000) Flood hazard assessment in Bangladesh using NOAA AVHRR data with geographical information system. Hydrol Process 14(3):605-620
14. Islam M, Sado K (2000) Satellite remote sensing data analysis for flood damaged zoning with gis for flood management. Ann J Hydraul Eng JSCE 44:301

15. Wiesnet DR, McGinnis DV, Pritchard JA (1974) Mapping of the 1973 Mississippi river floods by the NOAA-2. Satell Water Resour Bull 10(5):1040-1049

16. Chittibabu P, Dube SK, Macnabb JB et al (2004) Mitigation of flooding and cyclone hazard in Orissa, India. Nat Hazards 31:455. https ://doi.org/10.1023/B:NHAZ.0000023362.26409.22

17. Barman NK, Chetterjee S, Khan A (2014) Spatial variability of flood hazard risks in the Balasore Coastal Block, Odisha, India. J Geogr Nat Disast 4:120. https://doi.org/10.4172/2167-0587.1000120

18. Mishra S, aash J (2016) Hydro-morphology of cuts in coastal rivers debouching Chilika; South Mahanadi Delta, Odisha, India. Int J Adv Res 4:391-404. https://doi.org/10.21474/IJAR01/506

19. Agriculture Department Government of Odisha (2014) Disaster management plan for Odisha (Agriculture Sector) https://agrio disha.nic.in/content/pdf/DMP.pdf. Accessed March 2013

20. State Relief Commissioner-Odisha Odisha Floods Rapid Joint Needs Assessment Report (2014) http://www.sphereindia.org.in/Downl oad/16.08.2014\%20Odisha\%20Floods\%20Rapid\%20Joint\%20Nee ds\%20Assessment\%20Report-.pdf. Accessed 26 Aug 2014

21. Dar Manzoor, de Janvry Alain, Emerick Kyle, Raitzer David, Sadoulet Elisabeth (2013) Flood-tolerant rice reduces yield variability and raises expected yield, differentially benefitting socially disadvantaged groups. Sci Rep 3:3315. https://doi.org/10.1038/srep03315

22. Lu Zhong, Rykhus Russell, Masterlark Tim, Dean GK (2004) Mapping recent lava flows at Westdahl Volcano, Alaska, using radar and optical satellite imagery. Remote Sens Environ 91:345-353. https://doi.org/10.1016/j.rse.2004.03.015

23. Henry J-B, Chastanet P, Fellah K, Desnos YL (2006) Envisat multipolarized ASAR data for flood mapping. Int J Remote Sens 27(10):1921-1929. https://doi.org/10.1080/01431160500486724

24. Gstaiger V, Huth J, Gebhardt S, Wehrmann T, Kuenzer C (2012) Multisensoral and automated derivation of inundated areas using TerraSAR-X and ENVISAT ASAR data. Int J Remote Sens 33(22):72917304. https://doi.org/10.1080/01431161.2012.700421

25. Pierdicca Nazzareno, Pulvirenti Luca, Chini Marco, Guerriero Lorenzo, Candela L (2013) Observing floods from space: experience gained from COSMO-SkyMed observations. Acta Astronaut 84:122-133. https://doi.org/10.1016/j.actaastro.2012.10.034

26. Xiao Jingfeng, Li Jing, Moody A (2003) A detail-preserving and flexible adaptive filter for speckle suppression in SAR imagery. Int J Remote Sens 24(12):2451-2465. https://doi.org/10.1080/01431 160210154885

27. Zhou C, Luo J, Yang C, Li B, Wang S (2000) Flood monitoring using multi-temporal AVHRR and RADARSAT imagery. Photogramm Eng Remote Sens 66(5):633-638

28. Saaty TL (1980) The analytical hierarchy process: planning, priority setting, resource allocation. RWS Publication, Pittsburg

29. Radwan F, Alazba AA, Mossad A (2019) Flood risk assessment and mapping using AHP in arid and semiarid regions. Acta Geophys 67:215. https://doi.org/10.1007/s11600-018-0233-z

30. Getahun YS, Gebre SL (2015) Flood hazard assessment and mapping of flood inundation area of the Awash river basin in Ethiopia using GIS and HEC-GeoRAS/HEC-RAS model. J Civil Environ Eng 5:179. https://doi.org/10.4172/2165-784X.1000179

31. Assam State Disaster Management Authority (2007) Flood hazard classification http://asdma.gov.in/project_flood.html. Accessed 2007

Publisher's Note Springer Nature remains neutral with regard to jurisdictional claims in published maps and institutional affiliations. 